\title{
A critical review of recommendations to increase dietary protein requirements in the habitually active
}

\author{
Linda S. Lamont* \\ Department of Kinesiology, University of Rhode Island, Kingston, RI, USA
}

\begin{abstract}
Some scientists and professional organisations have called for an increase in dietary protein for those who reach a threshold level of exercise, i.e. endurance athletes. But there are individual scientists who question this recommendation. Limitations in the procedures used to justify changing the recommended daily allowance (RDA) are at issue. $\mathrm{N}$ balance has been used to justify this increase; but it is limiting even when measured in a well-controlled clinical research centre. Experimental shortcomings are only exacerbated when performed in a sports or exercise field setting. Another laboratory method used to justify this increase, the isotope infusion procedure, has methodological problems as well. Stable isotope infusion data collected during and after exercise cannot account for fed-state gains that counterbalance those exercise losses over a $24 \mathrm{~h}$ dietary period. The present review concludes that an adaptive metabolic demand model may be needed to accurately study the protein health of the active individual.
\end{abstract}

Key words: Nitrogen balance: Stable isotope tracer infusion: Protein recommended daily allowance for athletes: Dietary protein needs of athletes: Endurance athletes

\section{Introduction to the scientific dialogue}

Protein and amino acids only contribute $2-3 \%$ of the total energy needs during endurance exercise and it is unclear whether this leads to an increased demand for these nutrients $^{(1-3)}$. The debate as to whether dietary protein should be increased in those who habitually train has been ongoing. One position paper published in the year 2000 recommended an increase in dietary protein for the endurance athlete; however, this statement was revised in 2009 to indicate that no increase was necessary ${ }^{(4,5)}$. This issue has transcended the point where it is an academic discussion because it has affected a misunderstanding in the lay public about dietary protein health ${ }^{(2)}$. Nutrition supplement stores and on-line web sites consistently rank protein pills and powders among the top dietary aids sold ${ }^{(6)}$. These supplements are widely used but there appears to be a general misunderstanding about them. Young individuals are one age group that consumes and misuses supplemental amino acids and protein as nutritional aids ${ }^{(7-9)}$. A meta-analysis pooled fifty-one studies of 10000 high-school athletes and reported that nearly half the sample consumed supplements $(46 \%)^{(7,8)}$. But only ten out of 328 college athletes (3\%) were correctly able to identify the recommended daily protein energy needed for health ${ }^{(9)}$. About half the sample believed protein was the main energy source for muscle and onethird thought that protein supplementation was necessary to improve athletic performance ${ }^{(9)}$. These findings attest to a misunderstanding of exercise and protein health among those who exercise.

One serious problem with recommending an increase in dietary protein is that there are training-induced adaptations in amino acid economy that have not been accounted for in the laboratory methodologies used. In addition, modification of the $\mathrm{N}$ balance procedures to a sports field setting may be convenient ${ }^{(10-14)}$ but it presents numerous methodological shortcomings. Limitations of $\mathrm{N}$ balance, even when performed in a well-controlled clinical research setting, are known, and 25 years ago the nutritional scientist Dr Vernon Young ${ }^{(15)}$ cautioned that: '... nutritional balance studies have provided useful and important data about human protein and amino acid requirements, as well as about changes in protein and amino acid metabolism under various pathophysiological states. The technique is likely to continue to serve as a tool in nutritional studies, but its major limitations should be better appreciated. Reliance on this classical method as a principal procedure in studies of human nutrient requirements cannot be justified and, indeed, could be misleading.'

Abbreviation: RDA, recommended daily allowance.

*Corresponding author: Dr Linda Lamont, fax +1 401874 4215, email lamont@mail.uri.edu 
Although this quote was not directed to the sports nutrition community, the chance for making misleading recommendations using $\mathrm{N}$ balance data are just as relevant. Misunderstandings in the general public about protein nutrition attest to the need for a cautionary tone when giving dietary advice. The present review outlines this controversy and focuses on the experimental limitations in studying protein needs of the endurance athlete. It concludes that the recommendations to raise the protein recommended daily allowance (RDA) above that recommended for the healthy, sedentary adult have not been justified.

\section{Exercise studies using field-based metabolic balance}

Our ability to study whole-body protein metabolism is limited to a few procedures; one of the oldest is the $\mathrm{N}$ balance technique. $\mathrm{N}$ balance measurements require the collection of all $\mathrm{N}$ leaving and entering the subject in order to assess $\mathrm{N}$ equilibrium ${ }^{(16)}$. $\mathrm{N}$ output ( $\mathrm{N}$ leaving the body) is determined from the $\mathrm{N}$ in sweat, urine, faeces and other miscellaneous routes of elimination. $\mathrm{N}$ intake ( $\mathrm{N}$ entering the body) is determined by dietary analysis. Equilibrium (positive or negative $\mathrm{N}$ balance) is calculated from these $\mathrm{N}$ intake and output data. Professor John Waterlow ${ }^{(16)}$ published an extensive review of $\mathrm{N}$ balance in Nutrition Research Reviews many years ago. His review makes clear that $\mathrm{N}$ balance is a complex metabolic mystery that we do not fully understand. How changes in dietary protein translate into alterations in urea cycle activity still perplexes nutritional scientists. Recent research indicates that the urea cycle, comprised of five enzymes, requires additional enzymes and mitochondrial amino acid transporters to function and that major regulators of the liver's urea cycle enzyme expression include glucagon, insulin and glucocorticoids ${ }^{(17)}$. Urea $\mathrm{N}$ production can exceed $\mathrm{N}$ intake - and only through a transfer of the urea $\mathrm{N}$ produced to the colon, where it is hydrolysed into $\mathrm{NH}_{3}$, can $\mathrm{N}$ balance be attained. Urea kinetics measured during exercise demonstrated that there are increases in branched-chain amino acid oxidation without a simultaneous increase in the rate of urea production ${ }^{(18)}$.

Current dietary recommendations are that dietary protein should equal the intake necessary to maintain $\mathrm{N}$ equilibrium as measured with multi-level $\mathrm{N}$ balance studies. Although this procedure allows for the determination of positive or negative $\mathrm{N}$ balance, it does not reveal the specific ways in which a new state of balance has been achieved. The equilibrium measure known as the 'estimated average requirement' can be expressed as a reference value (mean +2 standard deviations). This reference or RDA can be used prescriptively to ensure that there will be a low risk of consuming less protein needed for optimal health ${ }^{(19,20)}$. The protein RDA for endurance athletes was amended in response to $\mathrm{N}$ balance analyses some years ago ${ }^{(4,21-25)}$. It was increased from
$0 \cdot 8 \mathrm{~g} / \mathrm{kg}$ per $\mathrm{d}$ as recommended for the healthy adult to $1 \cdot 2-1.4 \mathrm{~g} / \mathrm{kg}$ per $\mathrm{d}$ for the endurance athlete. Adoption of this nutritional change is now commonplace in sports nutrition textbooks ${ }^{(26-30)}$ but it has fallen short of scientific standards needed for its defence ${ }^{(1-3)}$.

$\mathrm{N}$ balance is far from an ideal laboratory procedure. When applied in a field setting the experimental limitations are accentuated and the data accuracy eroded because of a lack of control over the research environment. Fig. 1 outlines the measurements used in these exercise studies: sweat and/or urinary urea N (accounting for about 90\% of $\mathrm{N}$ excretion). But other routes of $\mathrm{N}$ output such as faecal, dermal or miscellaneous losses were not measured or were indirectly estimated ${ }^{(10-14)}$. Faecal $\mathrm{N}$ could have been detectable because not all protein is completely absorbed and $\mathrm{N}$ not reabsorbed is secreted into the gastrointestinal tract. Also there was a lack of measurement of urinary ammonia, uric acid and creatine which are substantial contributors to $\mathrm{N}$ output ${ }^{(19,31)}$. Renal blood flow and glomerular filtration rate decrease during prolonged exercise which further compounds the incomplete measure of $\mathrm{N}$ output in these balance studies ${ }^{(32)}$. Prolonged exercise can enhance urea reabsorption but it is unknown how these changes in kidney function influence urinary markers of whole-body protein catabolism ${ }^{(33)}$. Lastly, the slow turnover rate of the urea pool makes it difficult to determine the length of the collection period needed to ensure measurement accuracy ${ }^{(18)}$.

$\mathrm{N}$ balance studies of endurance athletes have been used to justify an increase in dietary protein but they have had methodological issues on the $\mathrm{N}$ input side of the balance equation as well. Alterations in protein intake can take weeks, if not months, to attain a new steady state in $\mathrm{N}$ metabolism ${ }^{(34)}$. When $\mathrm{N}$ intake is above minimum requirements (as is likely in many athletes), $\mathrm{N}$ balance remains unrealistically positive for a long time ${ }^{(35)}$. This is a methodological issue that has not been adequately addressed in sports nutrition experiments. Studies indicate that an adequate dietary control would require at least

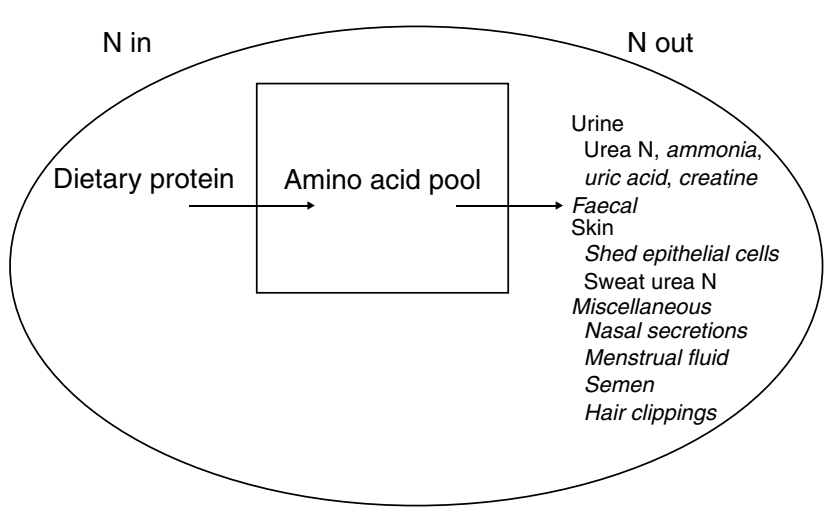

Fig. 1. The nitrogen balance model for determining protein requirements as adapted from Fukagawa \& Fisher ${ }^{(19)}$. Note those variables that are italicised have not been measured with the field-based nitrogen balance (some studies have estimated these). 
3-4 weeks and most have used an abbreviated dietary control period of $3-12 \mathrm{~d}$. This dietary approach is still being employed in $\mathrm{N}$ balance experiments ${ }^{(36)}$. Also fieldbased metabolic balance must by its very nature employ food diaries or dietary recall to estimate nutrient intake, a procedure known to produce issues with memory gaps and inconsistencies in judging portion $\operatorname{size}^{(37,38)}$. A few studies have used prepackaged meals as a way to control for protein intake; but subject compliance is difficult to ensure. The accuracy of measuring $\mathrm{N}$ input during the balance measurement can be highly dependent on the athlete's compliance. Lastly, because protein intake is provided and monitored in the field as opposed to a clinical research centre, software analysis of nutrient content provides an additional step for computational error.

Peripheral issues make an impact on the accuracy of field-based $\mathrm{N}$ balance measures as well. Criticisms of adapting $\mathrm{N}$ balance to the field setting include an inability to control for: state of aerobic training, steady-state energy balance, and habitual training intensity ${ }^{(39)}$. Previous research indicates that dietary protein efficiency adapts and $\mathrm{N}$ retention improves with aerobic training ${ }^{(40)}$. This previous experiment reported that protein requirements were reduced in the endurance athlete ${ }^{(40)}$ because of these training-induced adaptations in whole-body protein metabolism. This study underscores that experimental accuracy of field-based $\mathrm{N}$ balance measures is difficult to ensure. In addition, it highlights the impact of energy intakes on $\mathrm{N}$ balance and underscores that increases in energy intake in and of itself can improve both $\mathrm{N}$ retention and dietary protein efficiency ${ }^{(39,40)}$. Munroe highlighted some 30 years ago that $\mathrm{N}$ balance is extremely sensitive to energy intakes ${ }^{(41)}$ and there are reports of fasting subjects reducing $\mathrm{N}$ loss with just small amounts of non-protein energy ${ }^{(42)}$. Both dietary carbohydrate and fat reduce net whole-body protein use. Increases in daily energy intakes will reduce the need for protein to maintain $\mathrm{N}$ balance. In fact, $30 \%$ of the variance in $\mathrm{N}$ balance can be accounted for by energy intakes ${ }^{(43)}$. Cross-sectional comparisons between sedentary and well-trained subjects have not (and probably cannot) match for energy consumption. Because athletes require greater energy than their sedentary counterparts, field-based $\mathrm{N}$ balance studies will always be problematic. Another peripheral issue to the accuracy of $\mathrm{N}$ balance applied to the sports setting is that hydration influences urinary urea concentration in a manner independent of whole-body tissue protein breakdown ${ }^{(44)}$. High dietary protein intakes increase urea excretion (renal solute) that in turn heightens the need for water ${ }^{(44)}$. Finally, there are sex differences in the contribution of protein and amino acids to whole-body energy needs ${ }^{(45-48)}$ and these have not been included in the protein RDA recommendations for the habitually active.

One nutritional scientist cautions that making generalisations about protein health from $\mathrm{N}$ balance oversimplifies a very complex biochemical process ${ }^{(20)}$ and the reproducibility of the $\mathrm{N}$ balance method itself is poor ${ }^{(15)}$. These limitations exist even when performed in a wellcontrolled clinical research centre where test kitchens can strictly control for dietary intakes, physiological samples can be collected in total, and the activity level and energy balance of the subject can be strictly monitored and assured.

To summarise, the recommendation to increase protein intake, as determined from $\mathrm{N}$ balance, has had serious methodological problems on both the input and output sides of the equation. The procedure is a 'black-box' technique that does not allow for an assessment of the metabolic pathways involved in whole-body amino acid and protein metabolism. The estimates that this procedure has provided have often been unrealistic ${ }^{(2,44)}$. For instance, one sport scientist calculated that athletes placed on $2.5 \mathrm{~g}$ protein $/ \mathrm{kg}$ body weight per $\mathrm{d}$ had a positive $\mathrm{N}$ balance of $17 \mathrm{~g}$ each day. But this would be an impossible lean tissue gain of $110 \mathrm{~kg} / \mathrm{year}^{(2,13,44)}$. Some argue that errors such as these are due to an exercise-induced expansion of the circulating urea pool as well as a physiological limit to the rate of urea excretion ${ }^{(2)}$.

\section{Exercise tracer studies}

The accuracy of $\mathrm{N}$ balance can also be questioned because other biochemical procedures have provided contradictory experimental results. Contemporary studies of stable iso-

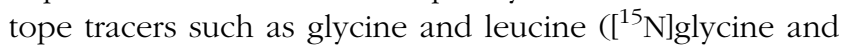
$\left[{ }^{13} \mathrm{C}\right]$ leucine) have been used to study whole-body protein metabolism in the endurance athlete. Glycine tracer methodology can be useful because a shorter experimental time will be necessary as $\mathrm{NH}_{3}$ is the endproduct sampled. This procedure has been standardised and validated ${ }^{(49)}$ and collection periods of $12 \mathrm{~h}$ have been found to be suitable to study whole-body protein metabolism ${ }^{(50,51)}$. A urea tracer, $\left[{ }^{15} \mathrm{~N}\right]$ urea, has also been studied but it is difficult to determine a suitable collection period because of the slow turnover rate of the urea pool. Whole-body protein turnover measured with the glycine isotope showed no difference between young and middle-aged endurance trained men or between sedentary men (although differences in $\mathrm{N}$ balance were found) ${ }^{(11)}$. No training effect was reported for protein turnover when glycine tracer experiments were conducted in young female gymnasts engaged in intensive training ${ }^{(52)}$. This tracer methodology was also used to study an unassisted Antarctic crossing that required extreme dietary energy intakes. These subjects maintained protein synthesis throughout this ultra-endurance event ${ }^{(53)}$.

A label of the essential amino acid leucine has also been used to study whole-body protein metabolism during endurance exercise and a comparison between the glycine and leucine tracer techniques has been performed ${ }^{(54)}$. A stable isotope infusion of the branched-chain amino acid $\left[1-{ }^{13} \mathrm{C}\right]$ leucine indicated that there was no difference in amino acid oxidation between rested, fasting endurance 
trained athletes when compared with age-, sex- and body weight-matched sedentary controls ${ }^{(55,56)}$. A 6 h study of leucine oxidation during resting conditions found that the athletes and sedentary controls had similar oxidation rates when expressed per unit of whole-body muscle mass ${ }^{(55)}$. This cross-sectional comparison suggests that habitual exercise does not alter resting protein needs. But when protein requirements are determined it will also be important to determine if there are physiological differences during exercise training.

Most athletes train a few hours each day and their need for protein will be altered if there is a prolonged increase in the use of this macronutrient for energy requirements. Branched-chain amino acid oxidation during aerobic exercise has been studied in numerous experiments ${ }^{(18,56-62)}$ and a graph of these can be found in Fig. 2. During prolonged exercise, leucine oxidation increases approximately two-fold over resting needs and this has been modestly correlated with oxygen consumption (exercise $\mathrm{V}_{\mathrm{O} 2}$; $R$ 0.69). This statistical relationship suggests that amino acid use during exercise can be regulated by many factors other than training intensity ${ }^{(63)}$ including: carbohydrate availability $^{(64,65)}, \mathrm{NADH} \mathrm{NAD}^{+}$ratio, acyl-CoA:CoA ratio, ketoacid availability ${ }^{(66)}$ and $\beta$-adrenergic receptor stimulation ${ }^{(58)}$. Also important to the athlete's requirement for dietary protein is the response during exercise recovery in which there are reports of a drop in leucine oxidation below resting values ${ }^{(57,67)}$.

Another important stable isotope tracer study ${ }^{(68)}$ highlighted that moderate exercise at energy balance does not affect leucine equilibrium or $\mathrm{N}$ retention over the subsequent $24 \mathrm{~h}$ period. The subjects were able to stay in leucine balance and had no additional protein need after undergoing two, 90 min exercises during both a fed and a fasted state. This underscores that acute increases in amino acid and protein use during exercise cannot be extrapolated to indicate that there will be an increased dietary requirement ${ }^{(68)}$. It also indicates that the protein requirement (protein RDA) can only be determined with an appropriate research design. The research design must account for both protein losses and gains throughout the diurnal cycle. Although this study reported that amino acid oxidation increased during exercise, this increase was offset throughout the daily feeding cycle.

There are other experiments that have measured wholebody amino acid and protein metabolism using research designs that allow for an assessment of training adaptations. These designs include: a cross-sectional comparison of trained and sedentary individuals as well as a brief exercise intervention. The cross-sectional comparison showed leucine oxidation to be similar in the well-trained athlete when compared with the untrained, sedentary control exercising at similar moderate intensities (half of maximal capacity). Amino acid oxidation expressed in relative terms, i.e. per unit of oxygen consumed (or fat-free mass) did not differ between endurance-trained $(28 \mu \mathrm{mol} / \mathrm{kg}$ body weight per litre oxygen) and sedentary control subjects (34 $\mu \mathrm{mol} / \mathrm{kg}$ body weight per litre oxygen $)^{(55)}$. This study does indicate that there are training-induced adaptations that lower the need for branched-chain amino acids, an observation consistent with the study by Butterfield \& Calloway that physical activity enhances protein efficiency ${ }^{(40)}$. An exercise intervention is another research design that can be used to study protein requirements for the habitually active $^{(56)}$. Subjects engaged in a $38 \mathrm{~d}$ training programme had a reduction in the oxidation of branched-chain amino acids and, importantly, a reduction in the regulatory enzyme in this oxidative pathway. Again, these data indicate that training-induced metabolic adaptations will decrease the need for whole-body amino acids and protein ${ }^{(56)}$. Both of these experiments contradict the recommendation to increase dietary protein in the habitually active individual. Instead, they indicate that small amounts of protein are used during exercise and that with training the need for this nutrient is down-regulated. Aerobic training causes an enhanced metabolic efficiency of protein used at the whole-body level. Table $1^{(18,55,69,70)}$ outlines that the absolute amount of whole-body protein oxidised during a $1 \mathrm{~h}$

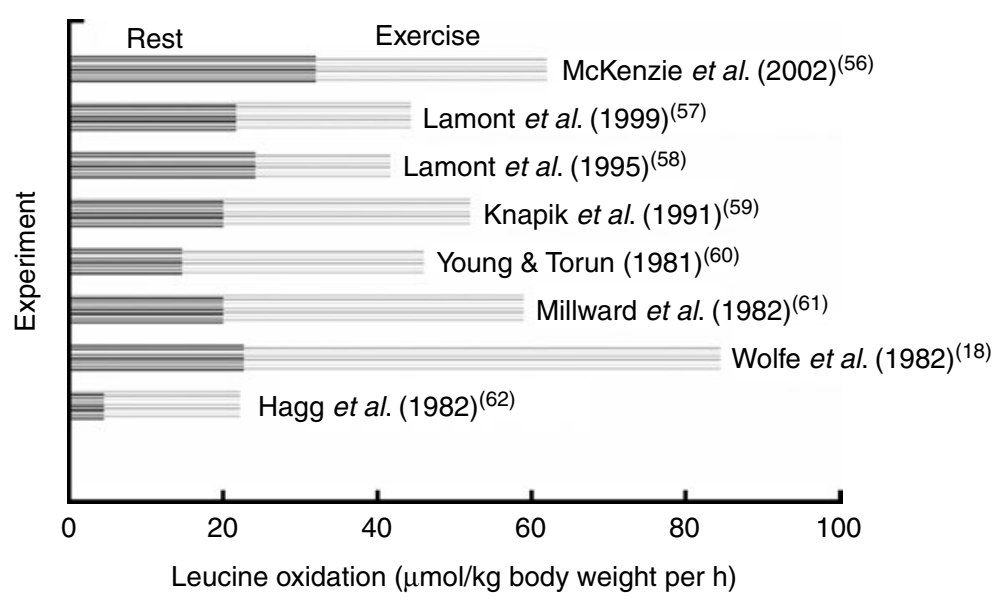

Fig. 2. Rate of leucine oxidation during acute endurance exercise. Redrawn using data from several sources ${ }^{(18,56-62)}$. 
Table 1. Whole-body protein oxidised during $1 \mathrm{~h}$ of moderate endurance exercise ${ }^{(70) \star}$

Leucine oxidation of well-trained endurance athlete who is

$77 \mathrm{~kg}$ body weight

$52 \mu \mathrm{mol}$ leucine oxidised/kg per $\mathrm{h}$ of exercise ${ }^{(55)}$

Assuming $590.0 \mu \mathrm{mol}$ leucine in each $\mathrm{g}$ of whole-body protein ${ }^{(18)}$

This cyclist would oxidise $6.77 \mathrm{~g}$ of whole-body protein during

a $1 \mathrm{~h}$ workout

$(52 \mu \mathrm{mol} \times 77 \mathrm{~kg} \times 1 \mathrm{~h}=6.77 \mathrm{~g}) \dagger$

By contrast, the daily need (using recommended changes in protein

RDA from 0.8 to $1.4 \mathrm{~g} / \mathrm{kg}$ ) would require this same athlete to

consume an additional $46.2 \mathrm{~g}$ protein per $\mathrm{d}$

$(77 \mathrm{~kg} \times 0.8 \mathrm{~g} / \mathrm{kg}=62 \mathrm{~g} / \mathrm{kg} \rightarrow 77 \mathrm{~kg} \times 1.4 \mathrm{~g} / \mathrm{kg}=108 \mathrm{~g} / \mathrm{kg})$

RDA, recommended daily allowance.

* The limitations of using leucine as a representative tracer of whole-body protein are acknowledged and discussed in depth elsewhere ${ }^{(70)}$

†This equals the amount of protein in one hard-boiled egg or one-third of a cup of cashew nuts ${ }^{(69)}$.

endurance exercise at half of maximal capacity is quite small and amounts to the protein in one egg or a small serving of cashew nuts. Some have argued that low to moderate exercise does not negatively make an impact on protein balance but the elite athlete engages in intense training and therefore will be at risk ${ }^{(31)}$. The subjects used for this computation were marathon runners, tri-athletes and long-distance cyclists and this calculation shows a marked inconsistency between the data provided by $\mathrm{N}$ balance and whole-body isotope infusion ${ }^{(31)}$.

\section{Time for a new approach?}

Problems inherent to $\mathrm{N}$ balance and the fact that whole-body stable isotope tracers provide contradictory calculations indicate that there are methodological problem(s). $\mathrm{N}$ balance has provided unreasonable estimates and attests to the warnings by many that this procedure is problematic ${ }^{(1-3)}$. Stable isotope experiments have been short term and cannot assess long-term adaptations or amino acid or protein balance throughout a daily feedingfasting cycle. This suggests that a new experimental model or laboratory procedure may be necessary to provide an accurate picture of protein health in the habitually active individual $^{(3,20)}$. Any new model must account for the various metabolic adaptations that occur with training such as: alterations in dietary protein efficiency, changes in the oxidative pathway of individual amino acids and changes in the intracellular reutilisation of amino acids from proteolytic pathways. An adaptive metabolic demand model as proposed by Millward ${ }^{(20)}$ may be useful to consider in this regard (see Fig. 3). Although this model is much more labour intensive, it has the potential to allow for an accurate assessment of the athlete's dietary protein needs. Both acute and chronic adaptations to a dietary change and/or alteration in exercise volume are incorporated into the model. As outlined in Fig. 3 it can be divided into: (1) a fixed component that meets obligatory demand; (2) a variable adaptive component that is relatively insensitive to short-term dietary manipulations and that can change over the long term; and (3) inter-individual (and training-induced) variations in dietary protein efficiency. In the athlete there are losses of amino acids and protein during the fasting state and with exercise, but there are fed-state gains. Amino acids may be used to fuel exercise energy needs



Fig. 3. Fate of dietary protein: an adaptive metabolic demand model of protein requirements as proposed by Millward ${ }^{(20)}$. This figure was altered with written permission to include those factors relevant to the sport nutrition setting. Note the addition of acute exercise and recovery effects on amino acid catabolism to the model. The adaptive behaviour of amino acid oxidation is a determinant of the metabolic demand for protein in the endurance athlete. 
but the contribution is small and this process has been shown to become more efficient with habitual training. In the endurance athlete, then, protein requirements would be defined as the intake needed to balance $\mathrm{N}$ losses (amino acids used during exercise and recovery). Lastly, a long-term study design needs to be employed to adequately account for feeding-state gains that replenish exercise losses. Other approaches maybe useful as well. Genomic and proteonomic studies may provide a new approach to studying this issue. But until agreement can be found between laboratory procedures it seems unwise to recommend a change in dietary protein intake for the habitually active individual.

\section{Conclusions}

There are public health consequences to recommending an increase in dietary protein consumption. Even moderate changes in dietary protein have metabolic consequences $^{(71)}$, not the least of which are alterations in the risk for chronic disease as well as negative impacts on cancer-protective metabolites in the colon ${ }^{(71-73)}$. In addition, many unsuspecting athletes are using amino acid supplements, protein powders and pills, and run the risk of ingesting contaminants in these unregulated products. Unnecessary amino acid supplementation can induce imbalances in amino acid ingestion that may cause adverse effects ${ }^{(74,75)}$. The laboratory techniques used to justify increasing the protein RDA has had numerous experimental limitations and therefore its accuracy is difficult to ensure. The 'black-box' nature of the balance model does not allow for the assessment of those metabolic adaptations and dietary efficiencies that accrue with chronic training. Short-term studies of amino acid oxidation during exercise cannot adequately account for fed-state gains over a $24 \mathrm{~h}$ diurnal period. These scientific shortcomings suggest that calls to increase the protein RDA for the habitually active or endurance athlete are not substantiated. A modification in laboratory procedures and methodology may provide greater fidelity to the dietary protein requirement for the habitually active individual.

\section{Acknowledgements}

The author would like to thank the faculty and staff of the Institute for Community Health Promotion, the Alpert Medical School at Brown University, Providence, Rhode Island. This paper was prepared while a Visiting Professor at this institution.

Sources of funding include the American Heart Association (grant no. AHA 91007450) and the National Institutes of Health (grants no. GCRC RR-00080 and GMS 2R25FM5178002).

This author has no conflicts of interest to report.

\section{References}

1. Renee MJ \& Tipton KD (2000) Protein and amino acid metabolism during and after exercise and the effects of nutrition. Ann Rev Nutr 20, 457-483.

2. Tipton KD \& Witard OC (2007) Protein requirements and recommendations for athletes: relevance of ivory tower arguments for practical recommendations. Clin Sports Med 26, 17-36.

3. Lamont LS (2009) History may be the best guide for determining the athlete's dietary protein needs. J Sports Sci Med 8, 150-151.

4. American Dietetic Association, Dietitians of Canada \& American College of Sports Medicine (2000) Position of the American Dietetic Association, Dietitians of Canada, and the American College of Sports Medicine: nutrition and athletic performance. Med Sci Sports Exerc 32, 2130-2145.

5. American Dietetic Association, Dietitians of Canada \& American College of Sports Medicine (2009) Joint position statement: nutrition and athletic performance. Med Sci Sports Exerc 41, 709-731.

6. Lawrence M \& Kirby D (2002) Nutrition and sports supplements: fact or fiction. J Clin Gastroenterol 35, 299-306.

7. Schwenk TL \& Costley CD (2001) When food becomes a drug: nonanabolic nutritional supplement use in athletes. Am J Sports Med 30, 907-916.

8. Williams M (2005) Dietary supplements and sports performance: amino acids. J Int Soc Sports Nutr 2, 63-67.

9. Rosenbloom CA, Jonnalagadda SS \& Skinner R (2002) Nutrition knowledge of collegiate athletes in a Division 1 National Collegiate Athletic Association institution. J Am Diet Assoc 102, 418-420

10. Fielding RA \& Parkington J (2002) What are the dietary protein requirements of physically active individuals? New evidence of exercise on protein utilization during postexercise recovery. Nutr Clin Care 5, 191-196.

11. Meredith CN, Zackin MJ \& Frontera WR (1989) Dietary protein requirements and body protein metabolism in endurance-trained men. J Appl Physiol 66, 2850-2856.

12. Friedman JE \& Lemon PWR (1989) Effect of chronic endurance exercise on retention of dietary protein. Int J Sports Med 10, 118-123.

13. Tarnopolsky MA, MacDougal JD, Atkinson SA, et al. (1988) Influence of protein intake and training status on nitrogen balance and lean body mass. J Appl Physiol 64, 187-193.

14. Gotzea I, Sutzescu P \& Dumitrache S (1974) The influence of muscular activity on nitrogen balance and on the need of man for protein. Nutr Rep Int 10, 35-43.

15. Young VE (1986) Nutritional balance studies: indicators of human requirements or of adaptive mechanisms? J Nutr 116, 700-703.

16. Waterlow JC (1999) The mysteries of nitrogen balance. Nutr Res Rev 12, 25-54.

17. Morris SM (2002) Regulation of enzymes of the urea cycle and arginine metabolism. Ann Rev Nutr 22, 87-105.

18. Wolfe RR, Goodenough RD, Wolfe MH, et al. (1982) Isotopic analysis of leucine and urea metabolism in exercising humans. J Appl Physiol 52, 458-466.

19. Fukagawa NK \& Fisher DY (1999) Protein and amino acid metabolism in elderly. In Methods for Investigation of Amino Acid and Protein Metabolism, pp. 167-177 [AE ElKhoury, editor]. Brighton, MA: CRC Press.

20. Millward DJ (2003) An adaptative metabolic demand model for protein and amino acid requirements. Br J Nutr 90, $249-260$

21. American College of Sports Medicine (2007) Position statement: the female athlete triad. Med Sci Sports Exerc 39, 1867-1882. 
22. Anonymous (1993) Position of the American Dietetic Association and the Canadian Dietetic Association: nutrition for physical fitness and athletic performance for adults. $J \mathrm{Am}$ Diet Assoc 93, 691-696.

23. Campbell B, Kreider RB, Ziegenfuss $T$, et al. (2007) International Society of Sports Nutrition position stand: protein and exercise. I Int Soc Sports Nutr $\mathbf{4}, 8$.

24. Lemon P (1996) Is increased dietary protein necessary or beneficial for individuals with a physically active lifestyle? Nutr Rev 54, S169-S175.

25. Lemon P (1998) Effects of exercise on dietary protein requirements. Int J Sports Nutr 8, 426-447.

26. Antonio J \& Stout JR (2001) Protein requirements for strength athletes: nitrogen balance. In Sports Supplements, pp. 302-305 [J Antonio and JR Stout, editors]. Philadelphia, PA: Lippincott Williams \& Wilkins.

27. Dunford M (2010) Protein. In Fundamentals of Sport and Exercise Nutrition, pp. 59-81 [M Dunford, editor]. Champaign, IL: Human Kinetics.

28. Fink HH, Burgoon LA \& Mikesky AE (2010) Endurance and ultra-endurance athletes. In Practical Applications in Sports Nutrition, 3rd ed., pp. 358-395 [HH Fink, LA Burgoon and AE Mikesky, editors]. Boston, MA: Jones and Bartlett.

29. Ketterly JE (2010) Performance nutrition. In National Academy of Sports Medicine's Essentials of Sports Performance Training, pp. 401-414 [MC Clark and SC Lucett, editors]. Philadelphia, PA: Wolters Kluwer Lippincott Williams \& Wilkins.

30. Williams MH (2007) Protein: the tissue builder. In Nutrition for Health, Fitness \& Sport, pp. 193-236 [MH Williams, $\mathrm{D}$ Anderson and E Rawson, editors]. New York, NY: McGraw Hill.

31. Tarnopolsky M (2004) Protein requirements for endurance athletes. Nutrition 20, 662-668.

32. Zambraski EJ (2006) The renal system. In ACSM's Advanced Exercise Physiology, pp. 521-531 [American College of Sports Medicine, editor]. Philadelphia, PA: Lippincott Williams \& Wilkins

33. Poortmans JR \& Vanderstraeten J (1994) Kidney function during exercise in healthy and diseased humans. An update. Sports Med 18, 419-437.

34. Quevedo MR, Price GM, Halliday D, et al. (1994) Nitrogen homeostasis in man: diurinal changes in nitrogen excretion, leucine oxidation and whole body leucine kinetics during a reduction from a high to a moderate protein intake. Clin Sci 86, 185-193.

35. Hegsted DM (1976) Balance studies. J Nutr 106, 307-311.

36. Rowlands DS \& Wadsworth DP (2011) Effect of high-protein feeding on performance and nitrogen balance in female cyclists. Med Sci Sports Exerc 43, 44-53.

37. Høidrup S, Andreasen AH, Osler M, et al. (2002) Assessment of habitual energy and macronutrient intake in adults: comparison of a seven day food recall with a dietary history interview. Eur J Clin Nutr 56, 105-113.

38. MacDiarmid JI \& Blundrel JE (1997) Dietary under-reporting: what people say about recording their food intake. Eur $J$ Clin Nutr 51, 199-200.

39. Butterfield GE (1987) Whole-body protein utilization in humans. Med Sci Sports Exerc 19, S157-S165.

40. Butterfield GE \& Calloway DH (1984) Physical activity improves protein utilization in young men. Br J Nutr 51, $171-184$.

41. Munro HN (1978) Energy and protein intakes as determinants of nitrogen balance. Kidney Int 14, 313-316.

42. Calloway DH \& Specter H (1954) Nitrogen balance as related to caloric and protein intake in active young men. Am J Clin Nutr 2, 405-412.
43. Pellet PL \& Young VR (1992) The effect of different levels of energy intake on protein metabolism and of different levels of protein intake on energy metabolism. In Protein-Energy Interactions, Proceedings of a $\mathrm{I} / \mathrm{D} / \mathrm{E} / \mathrm{G} / \mathrm{C}$ Workshop, pp. 81-121 [NS Schrimshaw and B Schürch, editors]. Lausanne, Switzerland: The Nestlé Foundation.

44. Jeukendrup A \& Gleeson M (2010) Protein and amino acids. In Sport Nutrition: An Introduction to Energy Production and Performance, 2nd ed., pp. 169-191 [A Jeukendrup and $\mathrm{M}$ Gleeson, editors]. Champaign, IL: Human Kinetics.

45. Tarnopolsky LJ, MacDougall JD, Atkinson SA, et al. (1990) Gender differences in substrate for endurance exercise. J Appl Physiol 68, 302-308.

46. Lamont LS, McCullough AJ \& Kalhan SC (2001) Gender differences in leucine, but not lysine, kinetics. J Appl Physiol 91, 357-362.

47. Lamont LS, McCullough AJ \& Kalhan SC (2003) Gender differences in the regulation of amino acid metabolism. J Appl Physiol 95, 1259-1265.

48. Lamont LS (2008) The dietary protein needs of the female athlete. Med Sci Sports Exerc 40, 588-589.

49. Grove G \& Jackson AA (1995) Measurement of protein turnover in normal man using the end-product method with oral $\left[{ }^{15} \mathrm{~N}\right] \mathrm{glycine}$ comparison of single-dose and intermittentdose regimens. Br J Nutr 74, 491-507.

50. Waterlow JC, Golden MHN \& Garlick PJ (1978) Protein turnover in man measured with ${ }^{15} \mathrm{~N}$ : comparison of end products and dose regimes. Am J Physiol Endocrinol Metab 4, E165-E174

51. Picou D \& Taylor-Roberts T (1968) The measurement of total protein synthesis and catabolism and nitrogen turnover in infants in different nutritional states and receiving different amounts of dietary protein. Clin Sci 36, 283-296.

52. Boisseau N, Persaud C, Jackson AA, et al. (2005) Training does not affect protein turnover in pre- and early pubertal female gymnasts. Eur J Appl Physiol 94, 262-267.

53. Stroud MA \& Jackson AA (1996) Protein turnover rates of two human subjects during an unassisted crossing of Antarctica. Br J Nutr 76, 165-174.

54. Duggleby SL \& Waterlow JC (2005) The end-product method of measuring whole-body protein turnover: a review of published results and a comparison with those obtained by leucine infusion. BrJ Nutr 94, 141-153.

55. Lamont LS, Patel DG \& Kalhan SC (1990) Leucine kinetics in endurance-trained humans. J Appl Physiol 69, 1-6.

56. McKenzie S, Phillips SM, Carter SL, et al. (2000) Endurance exercise training attenuates leucine oxidation and BCOAD activation during exercise in humans. Am J Physiol Endocrinol Metab 278, E580-E587.

57. Lamont LS, McCullough AJ \& Kalhan SC (1999) Comparison of leucine kinetics in endurance-trained and sedentary humans. J Appl Physiol 86, 320-325.

58. Lamont LS, McCullough AJ \& Kalhan SC (1995) $\beta$-Adrenergic blockade heightens the exercise-induced increase in leucine oxidation. Am J Physiol Endocrinol Metab 268, E910-E916.

59. Knapik JC, Meredith B, Jones R, et al. (1991) Leucine metabolism during fasting and exercise. J Appl Physiol 70, 43-47.

60. Young VR \& Torun B (1981) Symposium. In Nutrition in Health and Disease and International Development, XII International Congress of Nutrition, pp. 57-85 [AE Harper and GK Davis, editors]. New York: Alan R. Liss Inc.

61. Millward DJ, Davies CTM, Halliday D, et al. (1982) Effect of exercise on protein metabolism in humans as explored with stable isotopes. Fed Proc 21, 2686-2691.

62. Hagg SA, Morse EL \& Adibi SA (1982) Effect of exercise on rates of oxidation, turnover, and plasma clearance of leucine 
in human subjects. Am J Physiol Endocrinol Metab 242, E407-E410

63. Lamont LS, McCullough AJ \& Kalhan SC (2000) Relationship between leucine oxidation and oxygen consumption during steady-state exercise. Med Sci Sports Exerc 33, 237-241.

64. Wagenmakers AJM, Brookes JH, Coakley JH, et al. (1989) Exercise-induced activation of the branched-chain 2-oxy acid dehydrogenase in human muscle. Eur J Appl Physiol 59, 159-167.

65. Wagenmakers AJM, Beckers AJ, Brouns F, et al. (1991) Carbohydrate supplementation, glycogen depletion, and amino acid metabolism during exercise. Am J Physiol Endocrinol Metab 260, E883-E890.

66. Hood DA \& Terjung RL (1991) Effect of $\alpha$ ketoacid dehydrogenase phosphorylation on branched-chain amino acid metabolism in muscle. Am J Physiol Endocrinol Metab 261, E628-E634.

67. Devlin JT, Brodsky I \& Scrimgeour A (1990) Amino acid metabolism after intense exercise. Am J Physiol Endocrinol Metab 258, E249-E255.

68. el-Khoury AE, Forslund A, Olsson R, et al. (1997) Moderate exercise at energy balance does not affect 24-h leucine oxidation or nitrogen retention in healthy men. Am J Physiol Endocrinol Metab 273, E394-E407.
69. Nieman D (2011) Nutrition and performance. In Exercise Testing and Prescription: A Health-Related Approach, 7th ed., p. 267 [D Nieman, editor]. New York: McGraw Hill.

70. Bier DM \& Young VR (1984) Whole-body protein turnover: is leucine a representative tracer? In Branched Chain Amino and Keto Acids in Health and Disease, pp. 147-161 [SA Adibi, editor]. Basel: Karger.

71. Metges CC \& Barth CA (2000) Metabolic consequences of a high dietary-protein intake in adulthood: assessment of the available evidence. J Nutr 130, 886-889.

72. Fontana L, Klein S \& Holloszy JO (2006) Long-term low-protein, low-calorie diet and endurance exercise modulate metabolic factors associated with cancer risk. Am J Clin Nutr 84, 1456-1462.

73. Russell WR, Gratz SW, Dunan SH, et al. (2011) High-protein, reduced-carbohydrate weight-loss diets promote metabolite profiles likely to be detrimental to colonic health. Am J Clin Nutr 93, 1062-1072.

74. Barrett S \& Hebert V (1999) Fads, frauds, and quackery. In Modern Nutrition in Health and Disease, pp. 1793-1810 [ME Shils, JA Olson, M Shike and AC Ross, editors]. Baltimore, MD: Williams \& Wilkins.

75. Salmon WD (1958) The significance of amino acid imbalance in nutrition. Am J Clin Nutr 6, 487-494. 